\title{
Correlates of Steady State Lipid Profile and Anthropometric Parameters in Adult Sickle Cell Anaemia Patients in South-West Nigeria
}

\author{
Uche $\mathrm{Cl}^{1}$, Akinola $\mathrm{No}^{2}$ \\ Department Of Haematology And Blood Transfusion Abia State University Teaching Hospital Aba \\ Department Of Haematology And Blood Transfusion Obafemi Awolowo University Teaching Hospital Ile - Ife
}

\begin{abstract}
Introduction: Sickle cell anaemia is a genetic disorder characterized by chronic haemolytic state. Defective lipid in sickle cell anaemia has been attributed to increased cholesterol utilization consequent to increased erythropoiesis. Anthropometric measurements can easily reflect changes in the lipid deposition in the human body

This study aimed at correlating lipid profile and anthropometric parameters in Nigerian adults with SCA in steady state.

Method: The study is a cross sectional. A total of 58 homozygous haemoglobin SS (Hb SS) patients recruited from haematologyday ward of Obafemi Awolowo University Teaching Hospital Ile -Ife and 25 age and sexmatchedHb AA controls, selected from hospital workers, students and other members of the community were studied. Total cholesterol (TC), High density lipoproteins (HDL), Low density lipoproteins $(L D L)$, triglycerides and non-HDL-cholesterol were measured using Cholestech LDX (Cholestech Corporation U.S.A) from a single

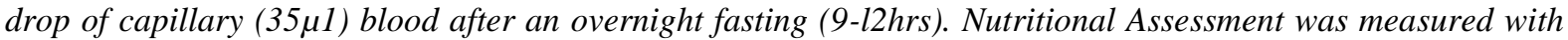
the aid of tape rule (for length and circumferences) while the skin fold thickness were measured using Caliper and weighing balance for weight. Data was analysed using excel and SPSS (version 20) statistical package.

Result: The study showed significant reduction in TC, LDL-c and HDL-c in patients compared with controls while there was no variation in TG in both patients and controls. However,about 57.9\% of SCA patients had normal levels of total cholesterol. There was strong correlation between the waist circumference and TC, LDL$c$ and triglyceride in sickle cell patients but not in control. Hip circumference correlated weakly with total cholesterol but strongly with triglyceride and LDL-c, Abdominal skin fold thickness (ABDSFT) correlated weakly with TG and LDL-c while mid thigh circumference (MTC) correlated weakly with LDL-c.

Conclusion: The anthropometric parameters correlated positively with total cholesterol and non-HDL cholesterol ( $L D L$-c and triglyceride) in sickle cell anaemia

Measuring of Waist circumference as well as Hip circumference(less strongly) may be surrogate markers for $T C, L D L-c$, and triglyceride in sickle cell anaemia
\end{abstract}

Keywords: Steady state, Sickle cell, lipid profile and anthropometric measurement.

\section{Introduction}

Hypocholesterolaemia has been described in various anaemias with high erythropoietic activity ${ }^{1-7}$. In Nigerian children with sickle cell anaemia (SCA) and African- American patients with sickle cell disorder a significant reduction in plasma cholesterol; high density lipoprotein (HDL-c) and low density lipoprotein (LDLc) cholesterol concentration compared to normal controls have been reported ${ }^{2,3}$ A study on adult with SCA reported low serum total cholesterol, LDL, HDL as well as lowered BMI compared to their controls. ${ }^{8}$ An earlier study noted a reduction in total cholesterol in boys and girls with SCD in Nigeria. ${ }^{9}$ While a more recent study conducted by the same group of researchers indicated that total cholesterol (TC) and LDL-cholesterol concentration were significantly reduced in African-American men and women with SCD in United State. ${ }^{2}$ They inferred that low levels of cholesterol might exacerbate the medical problems inherent in this genetic disorder. Literature reports of postmortem examinations on SCA patients confirmed the scarcity of coronary artherosclerosis and myocardial infarction. ${ }^{10}$ Defective lipid in sickle cell anaemia has been attributed to increased cholesterol utilization consequent to increased erythropoiesis as there is ongoing haemolysis as well as compensation by bone marrow ${ }^{4}$, however the pathogenesis is yet to be fully elucidated.

Abnormal long chain polyunsaturated (N-6 and N-3) fatty acid composition in the red cells has been found to be more remarkable in SCA than other sickle cell disorders. Studies done on the effect of alternative dietary lipid therapy showed that supplementation with N-3 fatty acid exerted a positive benefit on blood viscosity, platelet count, fibrinogen and fatty acid composition of red blood cells and platelets. ${ }^{11-13}$ 
Anthropometric measurements can easily reflect changes in the lipid deposition in the human body. Study shows that total cholesterol (TC), low density lipoprotein (LDL) and triglyceride (TG) increase with age and body mass index BMI ${ }^{14}$. Previous literature had reported reduction in these anthropometric ${ }^{15-16}$ measurements in children with sickle cell anaemia, however, there is paucity of literature on nutritional status in adult patients in this environment. This study was therefore aimed at correlating lipid profile and anthropometric parameters in Nigerian adults with SCA in steady state.

\section{Methods}

A total of 58 homozygous haemoglobin SS (Hb SS) patients recruited from haematology day ward of ObafemiAwolowo University Teaching Hospital Ile -Ife and 25 age and sex-matched $\mathrm{Hb}$ AA controls(selected from hospital workers, students and other members of the community) were studied. The demographic data of the patients and the controls including; name, age, sex, etc. were obtained by the aid of a well structured questionnaire.Steady state HbSS patients with no other concomitant sickness were included in the study while the controls included HbAA individuals who were not diabetic nor hypertensive neither smoke nor take excessive alcohol. Haemoglobin types of all the patients and controls were determined by the use of cellulose acetate electrophoresis at $\mathrm{pH} 8.4$, following standard protocols ${ }^{17}$

Sample size was determine using the formular ${ }^{18}: n=\left(\mathrm{z}^{2} \mathrm{pq}\right) / \mathrm{d}^{2}$, where $\mathbf{n}=$ sample size, $\mathbf{z}=$ critical value at $95 \%$ confidence level, usually set at $1.96, \mathbf{p}=$ Prevalence, $\mathbf{q}=1-\mathrm{p}, \mathbf{d}=$ precision of $5 \%(0.05) .{ }^{19}$ Prevalence of $3 \%$ was used as SCA affects $2-3 \%$ of Nigerians. ${ }^{19}$ Inputting variables in formula, $\mathrm{n}=\left(1.96^{2} \times 0.03 \times 0.97\right) / 0.05^{2}$ $=45$. Extra $26 \%$ patients were added to compensate for attrition leading to sample size of 58 .

Total cholesterol (TC), High density lipoproteins (HDL), Low density lipoproteins (LDL), triglycerides and non-HDL-cholesterol (HDL-c) were measured using Cholestech LDX (Cholestech Corporation U.S.A®). Total cholesterol, HDL-cholesterol, and triglyceride were measured simultaneously from a single drop of capillary $(35 \mu 1)$ blood after an overnight fasting (9-12hrs) using the Cholestech LDX systems®. Estimated LDL cholesterol is calculated using measured values.

Nutritional Assessment was measured with the aid of tape rule (for length and circumferences) while the skin fold thickness were measured using Caliper. The following were measured: body mass index BMI $\left(\mathrm{kg} / \mathrm{m}^{2}\right)$; mid-upper arm circumference MAC $(\mathrm{cm})$; mid-thigh circumference MTC $(\mathrm{cm})$; waist circumference WC $(\mathrm{cm})$; hip circumference HC (cm); and waist circumference/hip circumference ratio (WC/HC). Skin-fold thickness : mid-arm skin fold thickness MASFT (cm), abdominal skin-fold thickness ABDSFT (cm), thigh length (thigh $\mathrm{L} \mathrm{cm}$ ).

Statistical analysis : Data was analyzed using the Microsoft Excel and SPSS (version 20) statistical package. Continuous variables were presented using descriptive statistics [means, standard deviation (SD)] .Pearson's correlation test was used for the correlation test. A P-value $\leq 0.05$ was considered to be statistically significant.

\section{Results}

The sickle cell patients and controls studied were age and sex matched with comparable socioeconomic status and educational background.The mean age of the patients was $25.2 \pm 6.9$ years (range; 16-52) while that of thecontrols was $28.2 \pm 9$ years (range; 16-54; P >0.05). The male: female ratio was $1: 1.32$ for patients and 1: 1.27 for controls $(\mathrm{P}>0.05)$.

\subsection{Lipid Profile}

Out of 58 patients, 46 patients had measurable total cholesterol while 12 patients had no measureable levels, being less than $2.59 \mathrm{mmol} / \mathrm{l}$. The mean of total cholesterol for patients was $3.3 \pm 0.6 \mathrm{mmol} / \mathrm{l}$ and $4.0 \pm$ $0.9 \mathrm{mmol} / \mathrm{l}$ for the controls $(\mathrm{P}<0.0001)$ Table 1 . The mean of HDL-c for patients was $0.7 \pm 0.3 \mathrm{mmo} / \mathrm{l}$, and 1.1 $\pm 0.8 \mathrm{mmol} / \mathrm{l}$ for the controls $(\mathrm{P}<0.0001)$. The mean value of $\mathrm{TG}$ for both patients and controls was not significantly different. The mean LDL-c for patients was $2.1 \pm 0.5 \mathrm{mmol} / \mathrm{l}$ and it was significantly lower than that of the controls $(2.7 \pm 0.9 \mathrm{mmol} / 1 ; \mathrm{P}<0.01)$. However, about $57.9 \%$ of SCA patients had normal levels of total cholesterol The mean values of non-HDL and TC/HDL for patients $(2.5 \pm 0.6 \mathrm{mmol} / \mathrm{l}$, and $4.5 \pm 1.4)$ when compared with values for controls $(2.8 \pm 0.9 \mathrm{mmol} / 1,3.7 \pm 1.3$ respectively) were significantly different $(\mathrm{P}<$ 0.05). There was significant sex difference among male and female controls among whom females were found to have more HDL-cholesterol than males $(0.95 \pm 0.25,1.33 \pm 0.34 \mathrm{P}<0.05)$ respectively. There was however no sex difference in other lipid parameters among the patients.

\section{2nutritional Assessment}

The means of height in both patients and controls were $1.6 \pm 0.1 \mathrm{~m}$ and $1.7 \pm 0.1 \mathrm{~m}$, showing no significant difference $\mathrm{P}>0.05$ (Table $2 \mathrm{a}$ ). The mean values for weight and BMI were $52.2 \pm 9.9 \mathrm{~kg} ; 19.7 \pm 3.3$ $\mathrm{kg} / \mathrm{rn}^{2}$ respectively for patients and for the controls, $64.4 \pm 12.7 \mathrm{~kg} ; 23.1 \pm 4.5 \mathrm{~kg} / \mathrm{m}^{2}(\mathrm{P}<0.0001$ and $\mathrm{P}<0.001)$, 
were significant different. The mean values of MAC, MTC, HC, Thigh L for patients $(25.0 \pm 2.7 \mathrm{~cm} ; 42.5 \pm 5.1$ $\mathrm{cm} ; 82.3 \pm 8.2 \mathrm{~cm}$ and $48.8 \pm 5.3 \mathrm{~cm})$ and controls $(27.1 \pm 5.6 \mathrm{~cm} ; 48.2 \pm 6.1 \mathrm{~cm}, 89.0 \pm 10.6 \mathrm{~cm}$ and $51.2 \pm 3.1$ $\mathrm{cm} \quad(\mathrm{P}<0.05$; $\mathrm{P}<0.0001$; $\mathrm{P}<0.01$ and $<0.05)$ respectively were statistically significant. However the mean values of WC; MASFT and AbdSFT for both patients and controls were not significantly different

The waist circumference (WC) correlated significantly with total cholesterol, LDL and TG in sickle cell anaemia patients respectively $\mathrm{r}=0.483^{* *} ; \mathrm{P}=0.001 ; \mathrm{r}=0.476^{* *} ; \mathrm{P}=0.001$ but not in the control. Body mass index (BMI) correlated significantly with waist circumference $\left(\mathrm{r}=0.635^{* *} ; \mathrm{P}<0.000\right)$, mid-arm circumference $\left(\mathrm{r}=0.647^{* *} ; \mathrm{P}<0.000\right)$, mid thigh circumference $\left(\mathrm{r}=0.736^{* *} ; \mathrm{P}=0.000\right)$, hip circumference $\left(\mathrm{r}=0.599^{* *} ; \mathrm{P}<\right.$ $0.000)$, abdominal skin fold thickness $(\mathrm{r}=0.622 * * ; \mathrm{P}=0.000)$ in patients while in controls BMI correlated more strongly with waist circumference, mid thigh circumference, hip circumference $\left(r=0.755^{* *} ; \mathrm{r}=0.758^{* *} ; \mathrm{r}=\right.$ $\left.0.809^{* *} ; \mathrm{P}=0.000\right)$ and less strongly with mid arm skin fold thickness $(\mathrm{P}<0.05)$.

Table 1: Iipid profile of sickle cell patients and the controls

\begin{tabular}{|l|l|l|l|}
\hline Parameter & $\begin{array}{l}\text { Patients } \\
\text { Mean } \pm \text { Sd } \\
(\mathbf{N}=\mathbf{4 6})\end{array}$ & $\begin{array}{l}\text { Controls } \\
\text { Mean } \pm \text { Sd } \\
(\mathbf{N}=\mathbf{2 5})\end{array}$ & P-Value \\
\hline $\mathrm{Tc}(\mathrm{Mmol} / \mathrm{L})$ & $3.3 \pm 0.6$ & $4.0 \pm 0.9$ & $*<0001$ \\
\hline $\mathrm{Hdl}(\mathrm{Mmol} / \mathrm{L})$ & $0.7 \pm 0.3$ & $1.1 \pm 0.8$ & $*<0001$ \\
\hline $\mathrm{Tg}(\mathrm{Mmol} / \mathrm{L})$ & $1.1 \pm 0.5$ & $0.8 \pm 0.3$ & 0.078 \\
\hline $\mathrm{Ldl}(\mathrm{Mmol} / \mathrm{L})$ & $2.1 \pm 0.5$ & $2.7 \pm 0.9$ & $*<0.01$ \\
\hline $\mathrm{Non}-\mathrm{Hdl}(\mathrm{Mmol} / \mathrm{L})$ & $2.5 \pm 0.6$ & $2.8 \pm 0.9$ & $*<0.05$ \\
\hline $\mathrm{Tc} / \mathrm{Hdl}$ & $4.5 \pm 1.4$ & $3.7 \pm 1.2$ & $*<0.05$ \\
\hline
\end{tabular}

*significant $\mathrm{P}$ values.

Abbreviations: TC - Total Cholesterol, HDL - High density lipoprotein, TG -Triglyceride, LDL -low density lipoprotein,

Table 2: Nutritional status of sickle cell anaemia patients and controls

\begin{tabular}{|l|l|l|l|}
\hline Parameter & $\begin{array}{l}\text { Patients } \\
\text { Mean } \pm \text { Sd } \\
(\mathbf{N = 5 8})\end{array}$ & $\begin{array}{l}\text { Controls } \\
\text { Mean } \pm \text { Sd } \\
(\mathbf{N = 2 5})\end{array}$ & P-Value \\
\hline $\mathrm{Ht}(\mathrm{M})$ & $1.6 \pm 0.1$ & $1.7 \pm 0.1$ & Ns \\
\hline $\mathrm{Wt}(\mathrm{Kg})$ & $52.2 \pm 9.9$ & $64.4 \pm 12.7$ & $*<0.0001$ \\
\hline $\mathrm{Bmi}\left(\mathrm{Kg} / \mathrm{M}^{2}\right)$ & $19.7 \pm 3.3$ & $23.1 \pm 4.5$ & $*<0.0001$ \\
\hline $\mathrm{Mac}(\mathrm{Cm})$ & $25.0 \pm 2.7$ & $27.1 \pm 5.6$ & $*<0.05$ \\
\hline $\mathrm{Wc}(\mathrm{Cm})$ & $75.3 \pm 8.3$ & $74.8 \pm 10.2$ & Ns \\
\hline $\mathrm{Mtc}(\mathrm{Cm})$ & $42.5 \pm 5.1$ & $48.2 \pm 6.1$ & $*<0.0001$ \\
\hline $\mathrm{Hc}(\mathrm{Cm})$ & $82.3 \pm 8.2$ & $89.0 \pm 10.6$ & $*<0.01$ \\
\hline Masft $(\mathrm{Cm})$ & $24.0 \pm 8.3$ & $23.8 \pm 9.4$ & Ns \\
\hline Abdsft $(\mathrm{Cm})$ & $18.4 \pm 9.2$ & $18.6 \pm 8.6$ & Ns \\
\hline Thigh L $(\mathrm{Cm})$ & $48.8 \pm 5.3$ & $51.2 \pm 3.1$ & $*<0.05$ \\
\hline Wc/Hc & $0.92 \pm 0.1$ & $0.8 \pm 0.1$ & $*<0.05$ \\
\hline
\end{tabular}

* Significant $\mathrm{P}$ values.

Abbreviations: HT- height, WT- weight, BMI - boby mass index, MAC - mid arm circumference, WC- waist circumference, MTC, mid thigh circumference, HC - hip circumference, MASFT - mid arm skin fold thickness, ABDSFT - THIGHL- thigh length,

Table 3 Correlation of anthropometric parameters and lipid profilesin sickle cell anaemia patients

\begin{tabular}{|l|l|l|l|l|l|l|}
\hline $\begin{array}{l}\text { Anthropometric } \\
\text { Parameter }\end{array}$ & Tc & Hdl & Tg & Ldl & Nonhdl & Tc/Hdl \\
\hline Wt & 0.192 & 0.112 & -0.002 & 0.267 & 0.139 & 0.015 \\
R & 0.206 & 0.464 & 0.990 & 0.076 & 0.364 & 0.924 \\
\hline & & & & & & \\
\hline Ht & -0.027 & -0.1823 & 0.112 & 0.263 & 0.053 & 0.210 \\
R & 0.861 & 0.238 & 0.469 & 0.085 & 0.735 & 0.171 \\
\hline Bmi & & & & & & \\
R & 0.226 & 0.185 & 0.130 & 0.144 & 0.146 & -0.065 \\
P & 0.140 & 0.229 & 0.400 & 0.352 & 0.346 & 0.877 \\
\hline $\begin{array}{l}\text { Mac } \\
\text { R }\end{array}$ & 0.228 & 0.163 & 0.064 & 0.230 & 0.155 & -0.033 \\
\hline
\end{tabular}


Correlates of Steady State Lipid Profile and Anthropometric Parameters in Adult Sickle Cell ...

\begin{tabular}{|c|c|c|c|c|c|c|}
\hline $\mathrm{P}$ & 0.132 & 0.285 & 0.583 & 0.128 & 0.308 & 0.828 \\
\hline $\begin{array}{l}\mathrm{Wc} \\
\mathrm{R} \\
\mathrm{P}\end{array}$ & $\begin{array}{l}0.483 * * \\
0.001\end{array}$ & $\begin{array}{l}0.028 \\
0.856\end{array}$ & $\begin{array}{l}0.476^{* *} \\
0.001\end{array}$ & $\begin{array}{l}0.403 \text { ** } \\
0.006\end{array}$ & $\begin{array}{l}0.475^{\text {** }} \\
0.001\end{array}$ & $\begin{array}{l}0.190 \\
0.212\end{array}$ \\
\hline $\begin{array}{l}\text { Mtc } \\
\text { R } \\
P\end{array}$ & $\begin{array}{l}0.270 \\
0.073\end{array}$ & $\begin{array}{l}0.196 \\
0.196\end{array}$ & $\begin{array}{l}0.206 \\
0.174\end{array}$ & $\begin{array}{l}0.359^{*} \\
0.015\end{array}$ & $\begin{array}{l}0.186 \\
0.222\end{array}$ & $\begin{array}{l}-0.034 \\
0.830\end{array}$ \\
\hline $\begin{array}{l}\mathrm{Hc} \\
\mathrm{R} \\
\mathrm{P}\end{array}$ & $\begin{array}{l}0.376^{*} \\
0.011\end{array}$ & $\begin{array}{l}0.147 \\
0.336\end{array}$ & $\begin{array}{l}0.384 \text { ** } \\
0.009\end{array}$ & $\begin{array}{l}0.459 * * \\
0.002\end{array}$ & $\begin{array}{l}0.314^{*} \\
0.036\end{array}$ & $\begin{array}{l}-0.011 \\
0.942\end{array}$ \\
\hline $\begin{array}{l}\text { Masft } \\
\text { R } \\
\text { P }\end{array}$ & $\begin{array}{l}0.161 \\
0.291\end{array}$ & $\begin{array}{l}-0.175 \\
0.250\end{array}$ & $\begin{array}{l}0.182 \\
0.231\end{array}$ & $\begin{array}{l}0.125 \\
0.412\end{array}$ & $\begin{array}{l}0.243 \\
0.108\end{array}$ & $\begin{array}{l}0.266 \\
0.78\end{array}$ \\
\hline $\begin{array}{l}\text { Abdsft } \\
\text { R } \\
\text { P }\end{array}$ & $\begin{array}{l}0.194 \\
0.201\end{array}$ & $\begin{array}{l}0.110 \\
0.471\end{array}$ & $\begin{array}{l}0.327 * \\
0.028\end{array}$ & $\begin{array}{l}0.311^{*} \\
0.038\end{array}$ & $\begin{array}{l}0.148 \\
0.332\end{array}$ & $\begin{array}{l}-0.030 \\
0.845\end{array}$ \\
\hline $\begin{array}{l}\text { Thighl } \\
\text { R } \\
\text { P }\end{array}$ & $\begin{array}{l}0.0104 \\
0.498\end{array}$ & $\begin{array}{l}0.156 \\
0.306 \\
\end{array}$ & $\begin{array}{l}0.132 \\
0.386\end{array}$ & $\begin{array}{l}0.054 \\
0.734 \\
\end{array}$ & $\begin{array}{l}0.032 \\
0.833 \\
\end{array}$ & $\begin{array}{l}-0.047 \\
0.757 \\
\end{array}$ \\
\hline
\end{tabular}

*Statistical significant: **Correlation is significant at 0.01 level $(2$-tailed) $*$ Correlation significant at the 0.05 level(2-tailed)

The table showed strong correlation between the waist circumference and total cholesterol( $\mathrm{r}=0.483$; $\mathrm{p}=0.001)$, triglyceride $(\mathrm{r}=0.476 ; \mathrm{p}=0.001)$ and $\mathrm{LDL}(\mathrm{r}=0.403 ; \mathrm{p}=0.006)$. Hip circumference also correlated significantly with TC, TG and LDL (as shown in table 4 ). ABDTHICK correlated weakly with TG and LDL

\section{Discussion}

The study of lipid profile (Table 1) in sickle cell anaemia patients and their controls showed significant reduction in TC, LDL-c and HDL-c in patients compared with controls while there was no variation in TG in both patients and controls. These findings are in agreement with the observations of other workers. ${ }^{2}{ }^{8}{ }^{17}$. It was observed that even though the means of these values were lower than that of the controls, it was still within normal reference interval $(2.5-6.5 \mathrm{mmol} / \mathrm{l}$; Table 1$)$. Contrary to previous reports ${ }^{3-6,20}$ only one in five of these patients $(20 \%)$ had significant hypocholesterolaemia (TC $<2.59 \mathrm{mmol} / \mathrm{l})$. The hypocholesterolaemia may be a consequence of increased cholesterol utilization and/or decreased endogenous production. The reduced prevalence of hypocholesterolaemia observed in this series may be consequent to the improved nutritional status vis-a-vis normal mid-arm skin fold thickness, normal abdominal skin fold thickness observed in patients compared with the control (Tab 1, 2).. The implications of hypocholesterolaemia are far-reaching, with respect to red cell survival. Since there is always a free flow and exchange of cholesterol between the plasma and red cell membrane, a dynamic equilibrium is usually established. A condition in which plasma cholesterol is reduced would result in a shift in equilibrium with mobilization of membrane cholesterol (just like a buffer- system) to maintain the equilibrium. Red cell fragility and subsequent haemolysis usually result when membrane cholesterol is lowered beyond a critical level.

Previous studies have shown that body circumferences and body mass index (BMI) are used to measure adiposity and related health risks. ${ }^{21,22}$ Each circumference provides unique body composition and energy balance; for example waist circumference correlated strongly with visceral adipose tissue while hip circumference strongly correlates with subcutaneous adipose tissue, therefore waist and hip ratio are well correlated with adipose tissue distribution. Moreover, mid upper arm and calf circumference had highest association with skeletal muscle volumes. ${ }^{19,20}$ These studies also showed correlation between body circumferences and the BMI. In this present study, a linear correlation between BMI and MAC, WC, HC, MTC and AbdSFT was observed in both patients and controls. There was also a linear correlation between weight and BMI, MAC, WC, MTC and HC in both patients and controls. These correlations agree with previous studies that BMI and body circumferences in this series are measurements of adiposity. This study showed no significant difference between the height of patients when compared with controls (Table 2), but there is significant difference in the thigh length (control TL>, patient TL; P <0.05). There is also significant increase in the waist/hip (WC/HC ratio) in patient than in the control. The difference in thigh lengths and waist-hip ratio in the patients could be attributed to recurrent episodes of avascular necrosis of the femoral head leading to smaller hip circumference and shortening of the femur. There is no significant difference in means of MASFT AbdSFT, and WC of patients when compared with controls. This implies that this group of patients have good visceral and 
subcutaneous fat store. The reason could be attributed to an improved nutritional status. This finding is not in keeping with the previous literature. ${ }^{15,16}$

The significant difference in the mean WT, BMI, MAC and MTC of patients compared with controls obtained in this study is in keeping with reports elsewhere ${ }^{20-21}$ However BMI of SCD patients $(19.7 \mathrm{~kg} / \mathrm{rn} 2$ Table 2 ) is above the lower limit of normal reference range (18.5-25 kg/rn2). On the average the patients in this study had better than expected nutritional status.

Previous studies have reported a strong correlation between nutritional status and lipid profile. Flodmarket al observed that BMI significantly correlated with serum triglycerides ${ }^{22}$ Anderson et al reported that in adult men and women, the anthropometric measurements were inversely associated with levels of serum HDL-cholesterol. ${ }^{23}$ The findings of flodmark and Anderson are not in keeping with this present study. Another study showed that serum lipid concentrations had strong correlations with BMI. ${ }^{24}$ This study did not show any correlation between BMI and any of the lipid profile (Table 3). Another study found that visceral adipose tissue was significantly related to concentrations of plasma LDL-c and TG in 11-15 year-olds. ${ }^{25}$ In this study, there was strong correlation between the waist circumference (which correlates with visceral fat) and TC, LDL-c and triglyceride in sickle cell patients. Hip circumference correlated weakly with total cholesterol but strongly with triglyceride and LDL-c, ABDSFT correlated weakly with TG and LDL-c while mid thigh circumference (MTC) correlated weakly with LDL- c. On the whole, these anthropometric parameters correlated positively with nonHDL cholesterol which is more cardiotoxic than HDL-c. In clinical practice, the waist circumference (WC) has been recommended as a marker for visceral adipose tissue (VAT) ${ }^{26}$ Therefore waist circumference could be seen as a marker for non-HDL-c in sickle cell anaemia

\section{Conclusion}

The anthropometric parameters correlated positively with total cholesterol and non-HDL cholesterol (LDL-c and triglyceride) in sickle cell anaemia Measuring of Waist circumference as well as Hip circumference(less strongly) may be surrogate markers for TC, LDL-c, and triglyceride in sickle cell anaemia $57.9 \%$ of the patients had normal cholesterol indicating a paradigm shift therefore, further studies like total protein and albumin should be done in this group of patient to elucidate more on the nutritional status. Haematological parameters of these group of patients should be studied to see if this seemingly improved nutritional parameters have any impact on it.

\section{References}

[1]. Rahimia Z, Abmad M, Mansour Haghshenass, Plasma lipids in Iranians with sickle cell disease: Hypocholesterolemia in sickle cell anemia and increase of HDL-cholesterol in sickle cell trait, ClinicaChimicaActa, ; 365, 2006, 217-220.

[2]. Shores J, Peterson J, VanderJagt D, Glew RH. Reduced cholesterol levels in African-American adults with sickle cell disease. J NatI Med Assoc, 95, 2003, 813-817.

[3]. Erasmus RT, Olukoga AO, Ojuawo 0. Plasma lipids and lipoproteins in Nigerian children with sickle cell anemia. Ann Trop Paediatr. 10, 1990, 421-423.

[4]. Shalev H, Kapelushnik J, Asher M, et al. Hypocholesterolemia in Chronic Anaemias with Increased Erythropoietic Activity, Am J of Hematol 82 2007,199-202

[5]. Westerman MP. Hypocholesterolemia and anemia. Br J Haematol 31,1975, 87-94.

[6]. Schilling RF, Gangnon RE, Traver M. Arteriosclerotic events are less frequent in persons with chronic anemia: Evidence from families with hereditary spherocytosis. A m J Haematol , 81, 315-317.

[7]. Hartman C, Tamary H, Tamir A. Hypocholesterolemia in children and adolescents with $\beta$-thalassemia intermedia. J Pediatr , 141, 2002, 543-547.

[8]. Nagajoth N, Sanmugarajah J. Reduced Cholesterol 1evel in Adults with Sickle Cell Disease. Blood, 106 (1), 2005; 3808. Abstract.

[9]. Vanderjagt D, Shores J, Okorodudu A . Hypocholesterolemia in Nigerian children with sickle cell disease. Journal of Tropical Paed. 48. 2002 4156-161.

[10]. Barret N, Saurders D, Mcfarland D Myocardial infaction in Sickle Cell Anaemia. American Journal of Hematology, 16 (2), 2006,139-147.

[11]. Ren. H. Ghebremeskel K, Okpala I Ugochukwu CC,Crawford and Ibegbulam 0 Abnormality of erythrocyte membrane N-3 fatty acid in sickle cell HbSC disease is not as remarkable as in sickle cell anaemia HbSS. Prostaglandins LeukoEssent Fatty Acid 74, 2006,. 1-6.

[12]. Ren. H. Ghebremeskel K, Okpala I Ugochukwu CC,Crawford and Ibegbulam 0 Blood Mononuclear cells and platelets have abnormal FA compositions in Homozygous sickle cell disease Ann Hematol 8 (49) 2005 578-585.

[13]. Ren. H. Ghebremeskel K, Okpala I Ugochukwu CC,Crawford and Ibegbulam 0 Steady State Hemoglobin level in SCA increases with an increase in erythrocyte membrane N-3 fatty acid; Prostaglandins LeukoEssent Fatty Acid 72 (60), 2005, 415-421.

[14]. Rahman A, Al-Ajlan. Lipid profile in relation to anthropometric measurements among college male students in Radadh Saudi Arabia. International Journal of Biomedical Science: 7 (2) 2011;

[15]. Salman EK, Haymond MW, Bayne E, et al. Protein and energy metabolism in pre-pubertal Pediatr. Res. 40 (1) 1996 34-40

[16]. Barden E, Kawchack D, Frempong K, Body composition in children with sickle cell disease Am J Nutr, 76 (1), 2002, 218-225

[17]. Cheesbrough M. District Laboratory Practice in Tropical Countries, Part 2. Cambridge: Cambridge University Press; 2000. PCV and Haemoglobinelectrophoresis; pg.338-339

[18]. Kish L. Survey Sampling. New York: John Wiley and Sons; 1965.

[19]. World health organization, Fifty-ninth world health assembly. Provisional agenda item 11.4. 24 April 2006; A59/9. Sickle-cell anaemia. Report by the Secretariat 
[20]. Ugonabo MC .Plasma Lipid and Protein Levels Among Sickle Cell Anaemia Patients in Enugu 1997. Submitted to W.A.C.P. as part Two Dissertation [Unpublished]

[21]. Kuk IL, Janiszewski PM, Ross R: Body Mass index and hip and thigh circumferences are negatively associated with visceral adipose tissue after control for waist circumferences. Am. J. Clin. Nutr. 85, 2007, 1540-1544.

[22]. Steven B Heysmsfield, Allison Martin Nguyen: Body circumference: Clinical implications emerging from a new geometric model. Nutrition and Metabolism 5, 2008,1186/1743-7075

[23]. Flodmark CE, Sveger T, Nilsson-Ehle P. Waist measurement correlates to a potentially atherogenic lipoprotein profile in obese 12-1 4year old children. ActaPediatr 83, 1994, 941-945.

[24]. Anderson AJ, Sobocinski KA, Freedman DS, Barboriak JJ, Rimm AA, Gruchow H W. Body fat distribution, plasma lipids and lipoproteins. Arteriosclerosis 8 (8), 1988, 8-94.

[25]. Choi JW, Pal SH, Kim SK. Associations between total body fat and serum lipid concentrations in obese human adolescents. Annals Clin Lab Sci. 32 (3), 2002; 271-8.

[26]. Pouliot MC, Despres JP, Lemieux S, et al Waist circumference and abdominal sagittal diameter: best simple anthropometric indexes of abdominal visceral adipose tissue accumulation and related cardiovascular risk in men and women. Am J Cardiol 73 1994, 460-468. 